\title{
Analysis of the condition of forest interior and edge in Mount Papandayan, West Java, Indonesia based on floristic composition and structural characteristics of tree community
}

\author{
ENDAH SULISTYAWATI ${ }^{1, \boldsymbol{\nu}}$, EKA FATMAWATI TIHURUA ${ }^{1,2}$ \\ ${ }^{1}$ School of Life Sciences and Technology, Institut Teknologi Bandung. Labtek XI, Gedung SITH-ITB, Jl. Ganesa 10, Bandung 40132, West Java, \\ Indonesia. Tel.: +62-22-2511575, 2500258, Fax.: +62-22-2534107, "email: endah@sith.itb.ac.id \\ ${ }^{2}$ Research Center for Biology, Indonesian Institute of Sciences. Jl. Raya Jakarta-Bogor Km. 46, Cibinong, Bogor 16911, West Java, Indonesia
}

Manuscript received: 20 December 2018. Revision accepted: 28 February 2019.

\begin{abstract}
Sulistyawati E, Tihurua EF. 2019. Analysis of the condition of forest interior and edge in Mount Papandayan, West Java, Indonesia based on floristic composition and structural characteristics of tree community. Biodiversitas 20: $900-906 . \quad$ Forest fragmentation creates forest edges that possess different biotic characteristic in comparison to its interior. Those differences may include difference in vegetation structure and composition, and ecological processes in the ecosystem. This study aims to compare the condition between forest interior and forest edge in Mount Papandayan and provide assessment of the overall condition of the forest based on its floristic and structural characteristics. We conducted vegetation analysis of tree in which six plots, each of 0.1 ha, were established in the forest interior and forest edge. Based on the results, species richness and diversity of tree were higher in the forest interior than the forest edge. Based on the importance value index, the proportion of co-dominant species in forest edge sites were higher than in the forest interior sites. In addition, tree density, regeneration potential, total basal area, wood density average, and biomass were higher in the forest interior than in the forest edge. Overall, Mount Papandayan suffers moderate disturbance, which follows through the intermediate disturbance hypothesis and this can be seen from its relatively high diversity index of tree yet it has moderate wood density average.
\end{abstract}

Keywords: Regeneration potential, species diversity, tree biomass, tree density, wood density

\section{INTRODUCTION}

Forest fragmentation can cause smaller and relatively homogenous areas to form. This kind of area is also known as a patch. A forest patch located in an open landscape forms forest parts with different characteristics; the interior and edge forest. Characteristic differences between these two forest types are caused by edge effects as a result of interaction between two adjacent ecosystems (Murcia 1995).

Characteristic differences of the abiotic environment between the interior and edge forest will, in turn, affect some organisms or the ecosystem as a whole, such as their composition, structure, and processes inside the forest (Harper et al. 2005). Forest edges are generally made up of sun-tolerant species such as pioneer species with low wood density. On the other hand, species that grow inside forest interiors are those that are shade-tolerant, and in general, belong to climax species that have high wood density (Swaine and Whitmore 1988). However, in some cases, characteristic differences between forest interior and forest edge are not clear (Arruda and Eisenlohr 2016).

Characteristics differences between interior and edge of forest highlight how important it is to consider the shape of a conservation area (Murcia 1995). Conservation forests with many curves have longer edges which make the proportion of the forest edges greater than the interior in comparison to conservation areas which are rounder or more compact in shape. This suggests that for the conservation of species that dwell in forest interior, a more compact conservation area is desirable (Stiling 2012).

The forest of Mount Papandayan is a conservation area and can be seen as a remnant forest fragment on the landscape of West Java which has mostly been converted into farmlands, plantations, residential areas, and cities. Many aspects of the Mount Papandayan forest ecosystem have been studied, including its diversity and vegetation structure, floral phenology, and even its forest succession (Setiawan and Sulistyawati 2008; Sulistyawati et al. 2005; Sulistyawati et al. 2006; Sulistyawati et al. 2012). Nevertheless, a study specifically discussing the comparison of the condition between its interior and edge has never been done before. This study aims to compare the conditions of the interior and the edge forest of Mount Papandayan and provide assessment of the overall forest condition based on its floristic and structural characteristics. The floristic characteristics analyzed in this study were species richness, species diversity, as well as species dominance in the tree community. On the other hand, the structural characteristics discussed in this study were tree density, diameter distribution, total basal area, as well as wood density and biomass. In this study, wood density was used as one of the parameters to evaluate the condition of the forest since wood density gives indication of a plant's life strategy, forest succession stages, growth rate, mortality rate, biomass estimation, and carbon stock (Muller-Landau 2004; Woodcock 2000; Dias and Marenco 2016). 


\section{MATERIALS AND METHODS}

\section{Study area}

This study was conducted in the area of Mount Papandayan, which is located inside two regencies, Bandung District and Garut District of West Java Province, Indonesia. The climate of Mount Papandayan area is classified as type B according to the Schmidt and Ferguson classification with average annual rainfall of $3000 \mathrm{~mm}$. The average humidity is $70-80 \%$ with temperature of $10^{\circ} \mathrm{C}$ (BBKSDA Jabar 2018).

The forest in Mount Papandayan is a remnant forest; a result of forest fragmentation on the island of Java and is considered as a patch. The forest patch in Mount Papandayan stretches at 6,847 ha (Primajati et al. 2011) and stands at 2,665 $\mathrm{m}$ above sea level (ESDM 2018). The forest in Mount Papandayan is classified as an upper montane forest and sub-alpine (Van Steenis 2006) and has a number of vegetation types. Mount Papandayan has mixed forest vegetation, crater vegetation and savanna vegetation (Sulistyawati et al. 2005). More than 90 plant species have been discovered here. The area has different dominating plants in each vegetation type. Vaccinium varingiaefolium dominates the crater vegetation, the Distylium stellare and Cyathea latebrosa dominate the mixed forest vegetation, while the savanna vegetation is dominated by Imperata cylindrica (Sulistyawati et al. 2005).

Forest interior in this study is defined as part of the forest which lies inside the patch, while forest edge is the outermost part of the patch that is directly adjacent to former encroachment areas, tea plantations and other types of agricultural land. Three sites each were set in forest interior (INT) and forest edge (EDG). The three sites in the interior are located at $07^{\circ} 17^{\prime} 55,8^{\prime \prime} \mathrm{S}, 107^{\circ} 43^{\prime} 35,1^{\prime \prime} \mathrm{E}$ (INT 1), $07^{\circ} 17^{\prime} 24,1^{\prime \prime} \mathrm{S}, 107^{\circ} 43^{\prime} 35,2^{\prime \prime} \mathrm{E}$ (INT 2) and $07^{\circ} 17^{\prime} 16,1$ ' S, $107^{\circ} 43^{\prime} 31,4^{\prime \prime} \mathrm{E}$ (INT 3). Their closest distances to the edge are $1.2-6.2 \mathrm{~km}$. The three sites in the edge are located at $07^{\circ} 17^{\prime} 55,2^{\prime \prime} \mathrm{S}, 107^{\circ} 44^{\prime} 39,0^{\prime \prime} \mathrm{E}$ (EDG 1), $07^{\circ} 15^{\prime} 22^{\prime \prime} \mathrm{S}, 107^{\circ} 44^{\prime} 40,6^{\prime \prime} \mathrm{E}$ (EDG 2) and $07^{\circ} 15^{\prime} 17,9^{\prime \prime}$ S, $107^{\circ} 41^{\prime} 27,4^{\prime \prime} \mathrm{E}$ (EDG 3). All forest edge sites are located within $100 \mathrm{~m}$ from the nearest forest edges (Figure 1 and 2).

\section{Procedures}

Data collection was done by creating plots of $20 \times 50$ $\mathrm{m}^{2}$ which were randomly located in three sites of forest edge and three sites of interior forest. Each plot was then divided into 10 sub-plots of $10 \times 10 \mathrm{~m}^{2}$. Measurement was only done for trees, especially individuals with a diameter of $\geq 10 \mathrm{~cm}$ at breast-height level (about $1.3 \mathrm{~m}$ ).

Each tree diameter was measured and they were identified at species level. The total number of individuals of each species was also counted. Samples of each tree were taken for identification. Species identification was done by checking specimens in Herbarium Bogoriense, and Latin name validation of each species was done by checking the website www.theplantlist.org.

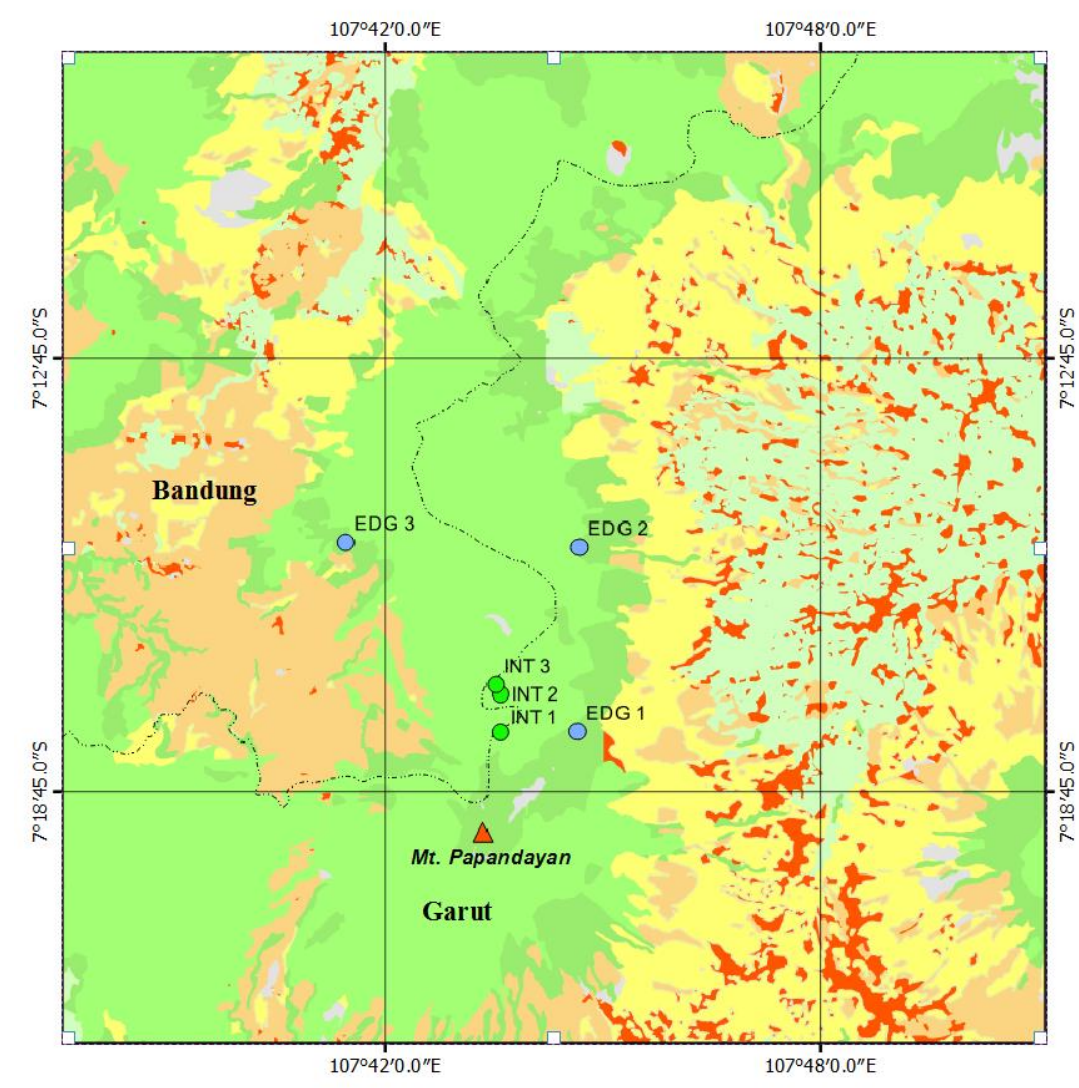

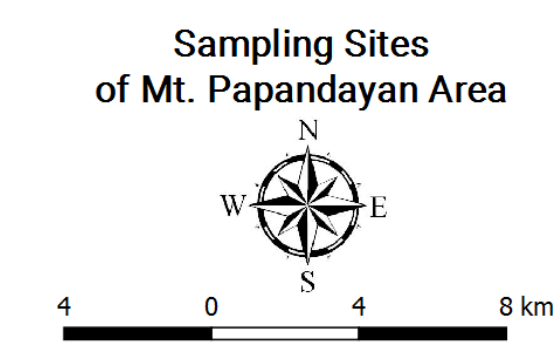

Legend:
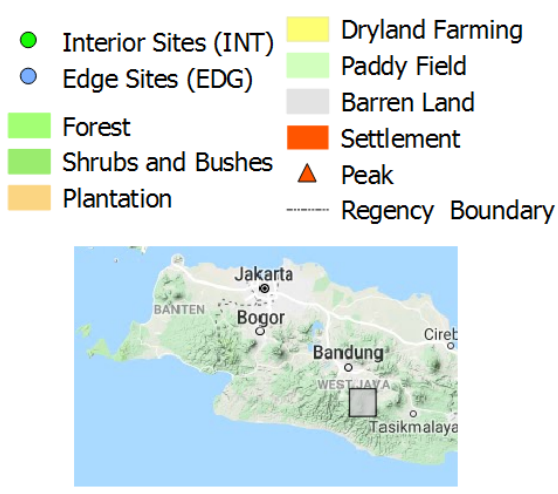

Map Source: - Topography map, scale 1:25000 Geospatial Information Agency

Figure 1. Study sites in Mount Papandayan, West Java, Indonesia 


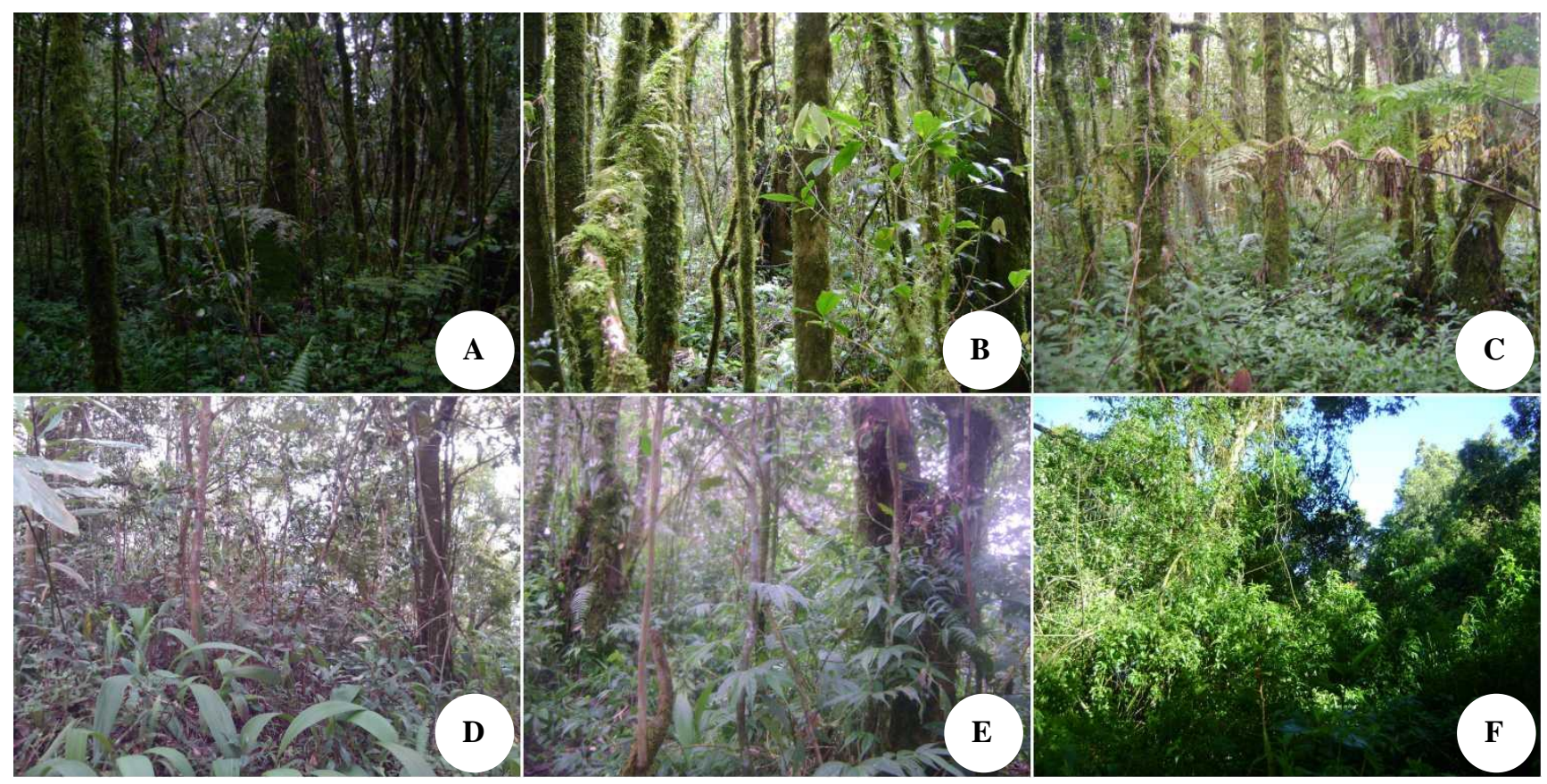

Figure 2. Forest interior (A-C)_and forest edge (D-F) in Mount Papandayan, West Java, Indonesia

\section{Data analysis}

Floristic characteristics analyzed in this study were species richness, importance value index of each species (Mueller-Dombois and Ellenbergh 1974), Simpson's dominance index (Odum 1971), and the Shannon-Wiener diversity index (Stiling 2012). Structural characteristics were reviewed using tree density, basal area, wood density average in each site and its above ground biomass of trees. Wood density data were collected from the World Agroforestry Database website (World Agroforestry 2017) and Oey (1990). In the case that data on wood density of a species was not available, the wood density of said species was estimated using the wood density average of every species of the same genus. The wood density average of the genus was used since wood density is conservative in nature at the genus level (Slik 2006). Then, the tree species was classified based on its wood density, which is heavy wood $(\rho>0.75)$, moderately heavy $(\rho=0.55-0.75)$, and light $(\rho<0.55)$ (Anoop and Pasha 2017). Estimation of the above-ground biomass of trees was calculated based on an allometric equation for moist forests using diameter and wood density (Chave et al. 2005).

\section{RESULTS AND DISCUSSION}

\section{Floristic characteristic}

This study recorded a total of 354 individuals from 29 species, 26 genera, and 20 families from the study sites. This result covers around $30 \%$ of the total discovered species in the area (Sulistyawati et al. 2005; Hamidi 2013; Setiawan 2008). The value of each characteristic of the sites within the interior and edge can be seen in Table 1. The value of species richness and diversity index indicates that the forest interior sites are home to more species and is more diverse than the forest edge sites.

Comparison with previous studies at other locations in Mount Papandayan on species presence (Table 2) shows that 18 species from a total of 29 species were present in parts of the forest similar to the parts of the forest in this study. Results of this study reveal that 14 species can be found in both the interior and edge of the forest, eight species can be found only in the interior, and seven species can be found only in the edge.

Based of the Importance Value Index (IVI), the proportion of some of the dominating (i.e., co-dominant) species was higher in sites within the forest edge sites compared to the forest interior sites. In every site within the forest interior, two species with the highest IVI made up approximately $39.64-46.73 \%$ of the total IVI (Table 3). By comparison, at the sites located within the forest edge, the two species with the highest IVI made up 46.86-74.83\% of the total IVI. Meanwhile, the Simpson dominance value index shows that no species has absolute dominance in any of the sites within the forest interior and edge. This can be seen from the low Simpson dominance value index of 0.130.37 in all of the sites.

Table 1. Floristic and structural characteristic values

\begin{tabular}{lcc}
\hline Plots & Species richness & $\begin{array}{c}\text { Shannon-Wiener diversity } \\
\text { index }\end{array}$ \\
\hline INT 1 & 16 & 2.31 \\
INT 2 & 12 & 2.10 \\
INT 3 & 12 & 2.18 \\
EDG 1 & 11 & 1.57 \\
EDG 2 & 13 & 2.14 \\
EDG 3 & 6 & 1.39 \\
\hline
\end{tabular}

Notes: INT: forest interior forest, EDG: forest edge 
Table 2. Species distribution in forest interior and edge based on study and references

\begin{tabular}{|c|c|c|c|c|}
\hline \multirow{2}{*}{ Species } & \multicolumn{2}{|c|}{ This study } & \multicolumn{2}{|c|}{ References } \\
\hline & INT & EDG & INT & EDG \\
\hline Distylium stellare Kuntze & + & + & 1 & 3 \\
\hline Engelhardtia spicata Lechen ex Bl. & + & + & - & 2,3 \\
\hline Helicia serrata $\mathrm{B} 1$. & + & + & 1 & 2,3 \\
\hline Lithocarpus elegans (B1.) Hatus ex Soepadmo & + & + & 1 & 2,3 \\
\hline Lithocarpus sundaicus (B1.) Rehder & + & + & 1 & 3 \\
\hline Litsea diversifolia $\mathrm{Bl}$. & + & + & 1 & 3 \\
\hline Macropanax dispermus (B1.) Kunzte & + & + & 1 & 1 \\
\hline Neolitsea javanica (B1.) Backer & + & + & 1 & $1,2,3$ \\
\hline Pyrenaria serrata $\mathrm{B} 1$. & + & + & 1 & - \\
\hline Schima wallichii Choisy & + & + & 1 & $2,3,4$ \\
\hline Symplocos lucida (Thunb.) Siebold \& Zucc. & + & + & 1 & 3 \\
\hline Syzygium lineatum (DC.) Merr. \& L. M. Perry & + & + & - & 3 \\
\hline Turpinia montana (B1.) Kurz & + & + & 1 & 2,3 \\
\hline Acronychya pedunculata (L.) Miq. & + & & 1 & - \\
\hline Antidesma montanum $\mathrm{Bl}$. & + & & 1 & - \\
\hline Astronia spectabilis $\mathrm{Bl}$. & + & & 1 & - \\
\hline Baccaurea javanica (B1.) Müll. Arg. & + & & NA & NA \\
\hline Dacrycarpus imbricatus (B1.) de Laub. & + & & 1 & - \\
\hline Podocarpus neriifolius D. Don & + & & 1 & - \\
\hline Polyosma illicifolia $\mathrm{Bl}$. & + & & 1 & - \\
\hline Symplocos adenophylla Wall. ex G. Don & + & & NA & NA \\
\hline Acer laurinum Hassk. & & + & 1 & 1,3 \\
\hline Castanopsis acuminatissima (B1.) A. DC. & & + & - & 3,4 \\
\hline Ficus grossularioides Burm.f. & & + & - & 5 \\
\hline Glochidion zeylanicum var arborescens (B1.) Chakrab. \& M. Gangop & & + & - & 3 \\
\hline Magnolia sumatrana var glauca (B1.) Figlar \& Noot. & & + & - & 1,3 \\
\hline Prunus arborea (B1.) Kalkman & & + & NA & NA \\
\hline Symplocos junghuhnii Koord. & & + & NA & NA \\
\hline
\end{tabular}

Notes: INT: forest interior, EDG: forest edge, NA: no information available. ${ }^{1}$ Hamidi (2013), ${ }^{2}$ Setiawan (2008), ${ }^{3}$ Wetadewi (2015),

${ }^{4}$ Marod et al. (2012), ${ }^{5}$ Backer and Bakhuizen van den Brink (1965)

Table 3. The two highest species Important Value Index (IVI) and Simpson's (C) dominance index in each site (plot 0.1 ha)

\begin{tabular}{|c|c|c|c|c|}
\hline Plots & & Species & IVI $(\%)$ & $\mathbf{C}$ \\
\hline \multirow[t]{6}{*}{ Interior forest } & INT 1 & Distylium stellare Kuntze & 83.07 & 0.13 \\
\hline & & Engelhardtia spicata Lechen ex Blume & 35.86 & \\
\hline & INT 2 & Engelhardtia spicata Lechen ex Blume & 71.09 & 0.17 \\
\hline & & Syzygium lineatum (DC.) Merr. \& L. M. Perry & 69.09 & \\
\hline & INT 3 & Syzygium lineatum (DC.) Merr. \& L. M. Perry & 67.48 & 0.15 \\
\hline & & Engelhardtia spicata Lechen ex Blume & 56.37 & \\
\hline \multirow[t]{6}{*}{ Edge forest } & EDG 1 & Schima wallichii Choisy & 120.35 & 0.37 \\
\hline & & Castanopsis acuminatissima (Blume) A. DC. & 92.23 & \\
\hline & EDG 2 & Lithocarpus sundaicus (Blume) Rehder & 76.98 & 0.15 \\
\hline & & Engelhardtia spicata Lechen ex Blume & 63.59 & \\
\hline & EDG 3 & Lithocarpus sundaicus (Blume) Rehder & 141.35 & 0.31 \\
\hline & & Macropanax dispermus (Blume) Kunzte & 83.13 & \\
\hline
\end{tabular}

\section{Structural characteristic}

Table 4 illustrates how the tree density in the forest interior sites is higher than in the forest edge sites. The distribution of the number of individuals of each diameter class (Figure 3) shows that in both forest types, the bigger the tree, the fewer the number of individuals.

The number of trees with the smallest and largest diameter class in the forest interior sites was higher than in the forest edge sites. Trees classified as the largest diameter class $(>99 \mathrm{~cm}$ ) could only be found in the forest interior sites. The presence of small trees suggests regeneration potential (Guariguata and Ostertag 2001). The average number of individuals in the smallest diameter class $(<20$ $\mathrm{cm}$ ) in the forest interior (28.3 individuals) is greater than in the forest edge (11.7 individuals). The fact that the forest interior sites host more small trees in comparison to the forest edge sites suggests that forest interior has a greater regeneration potential compared to forest edge. Furthermore, since the largest tree can only be found in the forest interior sites, this indicates that forest interior suffers less disturbance than forest edge. Illegal logging was the main disturbance occurring on the forest edge. 

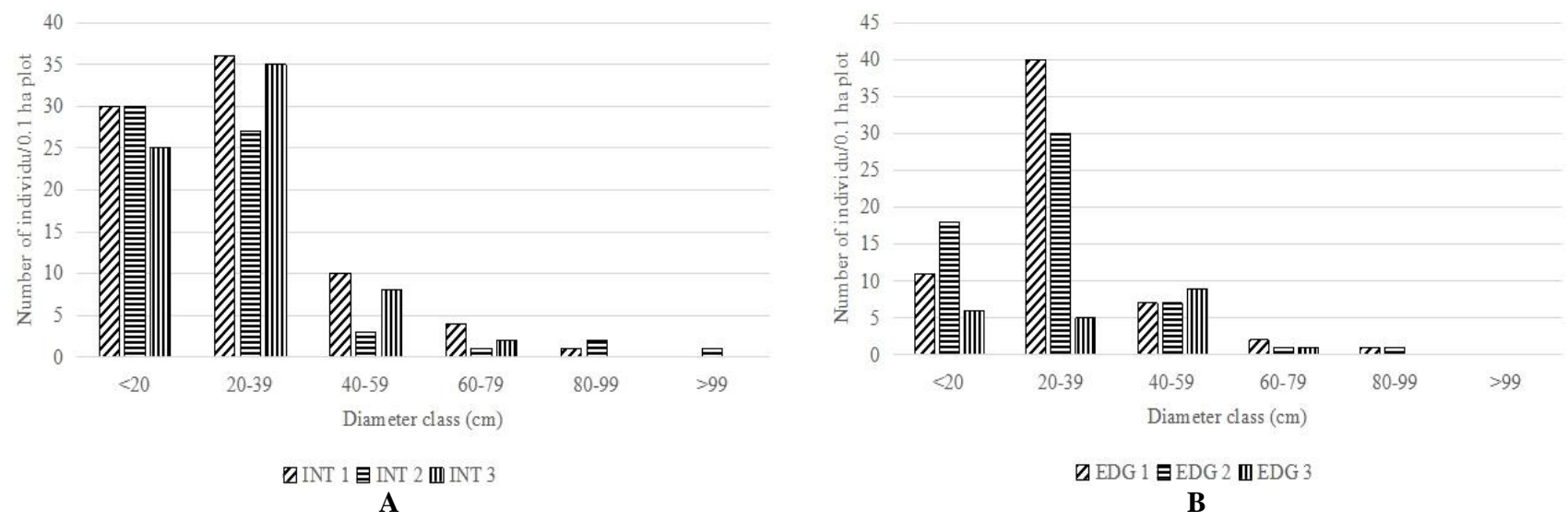

Figure 3. Individual distribution in diameter classes: A. Forest interior forest, B. Forest edge

Table 4. Value of structural characteristics

\begin{tabular}{lcccc}
\hline Plots & $\begin{array}{c}\text { Stem density } \\
\mathbf{h a}^{-\mathbf{1}}\end{array}$ & $\begin{array}{c}\text { Wasal area } \\
\left(\mathbf{m}^{\mathbf{2}} \mathbf{h a}^{-\mathbf{1}}\right)\end{array}$ & $\begin{array}{c}\text { Wood } \\
\text { density } \\
\text { average } \\
\left(\mathbf{g ~ c m}^{-3}\right)\end{array}$ & $\begin{array}{c}\text { Biomass } \\
\left(\mathbf{m g ~ h a}^{-1}\right)\end{array}$ \\
\hline INT 1 & 810 & 52.23 & 0.62 & 460.29 \\
INT 2 & 640 & 41.97 & 0.66 & 319.35 \\
INT 3 & 700 & 34.28 & 0.63 & 234.61 \\
Average & $717 \pm 86.22$ & $42.83 \pm 9.01$ & $0.63 \pm 0.02$ & $338.08 \pm 114.00$ \\
EDG 1 & 610 & 42.29 & 0.58 & 353.59 \\
EDG 2 & 570 & 34.26 & 0.58 & 286.18 \\
EDG 3 & 210 & 17.78 & 0.48 & 127.19 \\
Average & $463.33 \pm 220.3$ & $31.44 \pm 12.50$ & $0.55 \pm 0.05$ & $255.66 \pm 116.25$ \\
\hline
\end{tabular}

The total basal area average shows that the forest interior sites have a larger total basal area compared to the forest edge sites (Table 4). This is due to the forest interior sites having a higher tree density as well as a larger tree diameter average. Another structural characteristic is that the wood density average of the trees in all sites is classified as moderate $\left(0.58-0.66 \mathrm{~g} / \mathrm{cm}^{3}\right)$ except at EDG 3, which has a low wood density average (Table 4).

Above ground biomass accumulation in the forest interior sites was higher than in the forest edge sites. The estimation of above ground biomass in this study shows that INT 1 has the highest value, while EDG 3 has the lowest (Table 4). Based on the information gathered from the locals, anthropogenic disturbance associated with illegal logging on selected trees likely contributed to the lower above ground biomass in forest edge sites. Result of this study is in accordance with de Paula et al. (2011) reporting lower above ground biomass carbon in forest edges at highly fragmented landscape in northeast Brazil and Saeed et al. (2019) showing higher biomass carbon at forest interiors than forest edges along elevation gradients in Chinese Fir forest.

\section{Diversity and species distribution}

This study demonstrates that forest interior in Mount Papandayan is more diverse than its forest edge. This is in line with a study conducted in Tanzania by Kacholi (2014) in which tree richness and diversity of forest interior is higher than in forest edge. The aforementioned study also found that trees in forest interior are higher in density and have larger basal area compared to those in forest edge. The study by Kacholi (2014) and this study both indicate that edge effect influences species diversity. However, other studies in dry tropical forests found that the edge effect having no influence on species richness and diversity (Sampaio and Scariot 2011).

Some of the species that can only be found inside the forest interior sites were Podocarpus neriifolius and Dacrycarpus imbricatus. Both species are shade-tolerant during their juvenile stage, but develop a preference to require more sunlight as they grow (Fern 2018). Meanwhile, Castanopsis acuminatissima, which in this study was only found in the forest edge sites, is a fastgrowing species. This trait is the rationale of this plant being used as pioneer species for forest restoration in Thailand (Marod et al. 2012). Another species only found in the edge forest was Acer laurinum which bears winged fruit, a characteristic of a plant that relies upon wind as seed dispersal agent (Nasution 1994). However, in other studies, this species can also be found in forest interior (Hamidi 2013; Wetadewi, 2105). Species that can be found in both forest interior and edge, such as Lithocarpus elegans and L. sundaicus are species that are initially shade-tolerant but become more sun-tolerant as they grow (Fern 2018).

Engelhardtia spicata was another species found in both forest interior and edge sites (Table 2). The IVI of $E$. spicata was one of the highest in all forest interior sites and in one of forest edge sites. This indicates high abundance and widespread distribution of this species in Mount Papandayan. This is possibly due to E. spicata bearing fruits with wings as long as $5 \mathrm{~cm}$ (Van Steenis 2006), making this species is widely distributed in the forest of Mount Papandayan.

\section{The condition of Mount Papandayan}

Although all of the floristic and structural characteristics of forest interior were higher than in forest 
edge at the studied sites, this does not necessarily imply that the interior of Mount Papandayan forest has not experienced disturbance. Disturbance experienced by forest interior forest is generally lighter than forest edge. This can be seen from the fact that trees with the biggest size can only be found in the forest interior sites. Light disturbances are caused by naturally occurring factors such as lightning, wind storm, and tree mortality. These disturbances create gaps that allow sunlight to reach forest floors, and this stimulates growth of species that are sun-tolerant including pioneer species. This claim of the disturbance level in forest interior in Mount Papandayan is supported by its wood density value, which is categorized as moderate value (an average of $\rho=0.63 \mathrm{~g} / \mathrm{cm}^{3}$ ). The wood density value also indicates that in forest interior, the species that grow are not only climax species, but also pioneer ones. The results of this study support the study done by Primajati (2010) which stated that based on the observation using remote sensing, approximately 10-40\% of the interior forest area of Mount Papandayan is open forest.

Sites in forest edge have lower wood density compared to those within forest interior. This indicates that forest edge suffers heavier. This study is in line with the study conducted by Slik et al. (2008) which showed that the higher is the wood density, the lower is likely the level of disturbance experienced by the forest. The average wood density in EDG 3 is the lowest among all sites, indicating that EDG 3 experiences the heaviest disturbance. During data collection, it was observed that EDG 3 still experience disturbance in the form of forest encroachments from some humans around the area.

In general, the forest area in Mount Papandayan currently suffers moderate disturbance, as shown by its relatively high species diversity with an average of Shannon-Wiener diversity index of $1.95 \pm 0.37$ and that most sites have the index of more than two. This result is in accordance with the intermediate disturbance hypothesis suggested by Connel (1978) which stated that the highest species diversity occurs when a forest experiences moderate disturbance and that low species diversity occurs when a forest experiences heavier disturbance or no disturbance at all. In this study, this is also supported by the presence of species with low to high wood density within the area of Mount Papandayan with the trees having moderate wood density $\left(0.59 \mathrm{~g} / \mathrm{cm}^{3}\right)$.

\section{ACKNOWLEDGEMENTS}

We would like to thank the Nature Conservation Agency of West Java (Balai Besar Konservasi Sumber Daya Alam Jawa Barat) for granting permission, as well as the Indonesian Institute of Sciences. We also owe our thanks to Mang Ipin, Kang Iman, Kang Ade, Kang Rukman and Kang Agus for their hard work and contribution during field and laboratory research and Farid Rifaie for helping the preparation of the map. We also thank the reviewers who provided valuable feedback for improving the manuscript.

\section{REFERENCES}

Anoop EV, Pasha MKS. 2017. Timber identification manual: manual of timber used by wood-based handicrafts industry of Kerala, Uttar Pradesh, and Rajasthan. European Union /WWF India, New Delhi.

Arruda DM, Eisenlohr PV. 2016. Analyzing the edge effects in a Brazilian seasonally dry tropical forest, Brazilian J Biol. DOI: 10.1590/15196984.16014.

Backer CA, Bakhuizen van den Brink RC. 1965. Flora of Java. 2. Noordhoff, Groningen, The Netherlands.

BBKSDA Jabar. 2018. Cagar Alam Gunung Papandayan. https: //bbksdajabar.ksdae.menlhk.go.id/wp-content/uploads/2017/08/ProfilBidwil-3-Fix_skw_papandayan.pdf. Cited on May 22, 2018.

Chave J, Andalo C, Brown S, Cairns MA, Chambers JQ, Eamus D, Fölster H, Fromard F, Higuchi N, Kira T, Lescure JP, Nelson BW, Ogawa H, Puig H, Riéra B, Yamakura T. 2005. Tree allometry and improved estimation of carbon stocks and balance in tropical forests. Oecologia 145: 87-99.

Connell JH. 1978. Diversity in tropical rain forest and coral reefs. Science 199 (4335): 1302-1310.

De Paula, MD, Costa CPA, Tabarelli, M. 2011. carbon storage in a fragmented landscape of Atlantic forest: the role played by edgeaffected habitats and emergent trees. Trop Conserv Sci 4 (3): 349358.

Dias DP, Marenco RA. 2016. Tree growth, wood and bark water content of 28 Amazonian tree species in response to variations in rainfall and wood density. iForest 9: 445-451.

ESDM. 2018. G.Papandayan, Jawa Barat. www.vsi.esdm.go.id/index.php/gunungapi/data-dasar-gunungapi/211g-papandayan. Cited on May 22, 2018.

Fern K. 2018. Tropical Plants Database. Tropicaltheferns.info/viewtropical.php?id=Lithocarpus+elegans. Cited on September 11, 2018.

Guariguata MR, Ostertag R. 2001. Neotropical secondary forest succession: changes in structural dan functional characteristics. For Ecol Manag 148: 185-206.

Hamidi A. 2013. The environmental assessment study uses a floristic integrity approach: a case study of the Mount Papandayan nature reserve, West Java. [Thesis]. Bandung Institute of Technology, Bandung. [Indonesian].

Harper KA, MacDonald SE, Burton PJ, Chen J, Brosofske KD, Saunders SC, Euskirchen ES, Roberts D, Jaiteh MS, Esseen P. 2005. Edge influence on forest structure and composition in fragmented landscapes. Conserv Biol 19 (3): 768-782.

Kacholi DS. 2014. Edge-interior disparities in tree species and structural composition of the Kilengwe forest in Morogoro region, Tanzania. ISRN Biodiversity. DOI: 10.1155/2014/873174.

Marod D., A-sanok L, Duengkae P, Pattanavibool A. 2012. Vegetation structure and floristic composition along the edge of montane forest and agricultural land in Um Phang wildlife sanctuary, Western Thailand. Kasetsart J Nat Sci 46: 162-180.

Mueller-Dombois D, Ellenberg H. 1974. Aims and Methods of Vegetations Ecology. John Wiley \& Sons, Inc., New York.

Muller-Landau HC. 2004. Interspecific and inter-site variation in wood specific gravity of tropical trees. Biotropica 36 (1): 20-32.

Murcia C. 1995. Edge effects in fragmented forests: implication for conservation. Tree 10 (2): 58-62.

Nasution RE. 1994. Acer L. In Sosef MSM, Hong LT, Prawirohatmodjo S (Eds). Plant Resources of South-East Asia No 5 (3), Timber trees: Lesser-known timbers. Backhuys Publisher, Leiden, the Netherland.

Odum EP. 1971. Fundamentals of Ecology. 3rd ed. Saunders College Publishing, New York.

Oey DS. 1990. Berat jenis dari jenis-jenis kayu Indonesia dan pengertian beratnya kayu untuk keperluan praktek. Pusat Penelitian dan Pengembangan Hasil Hutan, Bogor. [Indonesian]

Primajati M, Harto AB, Sulistyawati E. 2011. Forest condition analysis based on forest canopy closure with remote sensing approach. Jurnal Biologi Indonesia 7 (1): 13-23. [Indonesian]

Primajati M. 2010. Analysis of the landscape of the Papandayan Mountain region based on SPOT satellite imagery (Undergraduate thesis). Bandung Institute of Technology, Bandung. [Indonesian]

Saeed S, Yujun S, Beckline M, Chen L, Zhang B, Ahmad A, Mannan A, Khan A, Iqbal A. 2019. Forest edge effect on biomass carbon along altitudinal gradient in Chinese fir (Cunninghamia lanceolata): A 
study from Southeastern China. Carbon Manag. DOI: 10.1080/17583004.2018.1537517

Sampaio AB, Scariot A. 2011. Edge effect on tree diversity, composition, and structure in a deciduous dry forest in Central Brazil. Revista Árvore, Viçosa-MG 35 (5): 1121-1134.

Setiawan NN, Sulistyawati E. 2008. Succession following reforestation on abandoned fields in Mount Papandayan, West Java. Internationa Conference on Environmental Research and Technology (ICERT 2008) < Penang, Malaysia, 28-30 May 2008.

Setiawan NN. 2008. The structure and composition of vegetation on exreforested fields in the Papandayan Mountain Reserve, West Java. [Hon. Thesis]. Bandung Institute of Technology, Bandung. [Indonesian]

Slik JWF, Bernard CS, Breman FC, Van Beek M, Salim A, Sheil D. 2008 Wood density as a conservation tool: quantification of disturbance and identification of conservation-priority areas in tropical forests. Conserv Biol 22 (5): 1299-1308.

Slik JWF. 2006. Estimating species-specific wood density from the genus average in Indonesian trees. J Trop Ecol 22: 481-482.

Stiling P. 2012. Ecology: Global Insight and Investigations. McGrawHill, New York.

Sulistyawati E, Mashita N, Setiawan NN, Choesin DN, Suryana P. 2012. Flowering and fruiting phenology of tree species in Mount
Papandayan Nature Reserve, West Java, Indonesia. Trop Life Sci Res 23 (2): 81-95.

Sulistyawati E, RM Sungkar, Maryani E, Aribowo M, Rosleine D. 2006. The biodiversity of Mount Papandayan and the threats. Presentation on International Interdisciplinary Conference Volcano International Gathering 2006 " 1000 years Merapi Paroxysmal Eruption", Volcano: Live, Prosperity, and Harmony, Yogyakarta, Indonesia. September 7, 2006.

Sulistyawati E, Rosleine D, Sungkar RM, Gurnita. 2005. Struktur komunitas dan keanekaragaman tumbuhan di G. Papandayan. Presentation on Seminar Penggalang Taksonomi Tumbuhan Indonesia. Universitas Pendidikan Indonesia, Bandung, November 18-19, 2005. [Indonesian]

Swaine MD, Whitmore TC. 1988. On the definition of ecological species groups in tropical rain forests. Vegetatio 75: 81-86.

Van Steenis CGGJ. 2006. Mountain flora of Java, 2nd ed. E.J. Brill, Leiden.

Wetadewi RI. 2015. Forest regeneration on the edge of the Papandayan Mountain Nature Reserve, West Java. [Hon. Thesis]. Bandung Institute of Technology, Bandung. [Indonesian].

Woodcock DW. 2000. Wood specific gravity of trees and forest types in the southern Peruvian Amazon. Acta Amazonica 30 (4): 589-599.

World Agroforestry. 2017. Wood Density Data. http: //db.worldagroforestry.org/wd. Wood density data. Cited on 2017. 